\title{
A Case of Neurosyphilis Presenting with Multiple Cranial Neuropathy
}

\author{
Çoklu Kafa Çifti Tutulumuyla Seyreden Bir Nörosifiliz Olgusu
}

\author{
Eda Kılıç Çoban, Mehmet Ali Aldan, Sedat Gez, Nilüfer Kale, Mesude Özerden, Nazan Sakallı, Aysun Soysal \\ Bakırköy Training and Research Hospital of Psychiatry, $3^{\text {rd }}$ Clinic of Neurology and Neurosurgery, İstanbul, Turkey
}

\section{Summary}

Syphilis is a sexually-transmitted disease caused by the spirochete bacterium Treponema pallidum. Central nervous system involvement can occur in every stage of the disease. It is classified into: acute syphilitic meningitis, meningovascular syphilis, and parenchymatous neurosyphilis. Acute basilar syphilitic meningitis is characterized primarily by the presence of cranial nerve involvement. As cranial nerve enhancement may be seen in a broad range of diseases, it can be the only clinical feature of neurosyphilis.

Keywords: Neurosyphilis, cranial neuropathy, meningitis

\section{$\ddot{O} \mathbf{z}$}

Sifiliz, bir spiroket olan Treponema pallidum tarafından oluşan cinsel yolla bulaşan bir hastalıktır. Hastalıkta merkezi sinir sistemi tutulumu her dönemde gözlenebilir. Hastalık en sık akut sifilitik menenjit, meningovasküler sifiliz ve parankimal nörosifiliz olarak karşımıza çıkar. Akut baziller sifilitik menenjit primer olarak kafa çifti tutulumu ile kendini gösterir. Çoklu kafa çiftleri mevcudiyeti merkezi sinir sistemi tutulumu yapan pek çok hastalıkta görülebilmekle birlikte nörosifilizin de tek klinik bulgusu olabilir.

Anahtar Kelimeler: Nörosifiliz, kafa çiftleri, menenjit

\section{Introduction}

Neurosyphilis is a sexually-transmitted infection caused by the spirochete bacterium Treponema pallidum. It is associated with chronic course, reactivation, and multisystemic involvement. The microorganism enters the central nervous system (CNS) after an inoculation period, which takes 3-18 months. CNS involvement can be seen anytime in the course of the disease. Acute syphilitic meningitis, meningovascular syphilis, and parenchymal neurosyphilis are the most common forms of the disease. Syphilitic meningitis is thought to be caused by small vessel artheritisassociated direct meningeal inflammation and occurs two years after the initial exposure. Acute basilar syphilitic meningitis presents with cranial nerve involvement.

Multiple cranial nerve involvements with ocular findings can be seen in various diseases with CNS involvements such as neurosyphilis (1). Herein, we report a patient who presented with cranial neuropathies, predominantly with visual disturbances, but without meningeal irritation signs, to draw attention to neurosyphilis.

\section{Case Report}

A man aged 38 years was admitted to the emergency department with double vision, right eyelid dropping, numbness

\footnotetext{
Address for Correspondence/Yazışma Adresi: Eda Kılıç Çoban MD, Bakırköy Training and Research Hospital of Psychiatry, Clinic of Neurology and Neurosurgery $3^{\text {rd }}$, İstanbul, Turkey Phone: +90 $2125436565-1840$ E-mail: eda_coban@yahoo.com

Received/Geliş Tarihi: 11.12.2014 Accepted/Kabul Tarihi: 04.03.2015

(c) Turkish Journal of Neurology, Published by Galenos Publishing House.

This article is distributed under the terms of the "Creative Commons Attribution NonCommercial 4.0 International Licence (CC BY-NC 4.0)".
} 
on the left side of his face, and hearing loss on the left side. Neurologic examination showed right ptosis, restriction of right eye movements except lateral gaze, and hypoesthesia on the right side of the face in the trigeminal trace. The right pupil size was 5 millimeters in diameter (Figure 1,2). The sense of vibration in then lower extremities was decreased. There were no signs of meningeal irritation. Cranial magnetic resonance imaging (MRI) showed contrast enhancement in the right oculomotor, bilateral trigeminal, facial, vestibulocochlear nerve roots (Figure 3, 4). An audiogram showed mild sensorineurol hearing loss in the left ear. Eighty lymphocytes were counted in cerebrospinal fluid (CSF) and the protein level of CSF was $51.9 \mathrm{mg} / \mathrm{dL}$. Venereal Disease Research Laboratory (VDRL) test was negative in the CSF sample. VDRL-rapid plasma reagin (RPR) (1/16) and Treponema pallidum hemagglutination assay (TPHA) (1/5210) tests were positive in the serum sample, and the fluorescent treponemal antibody (FTA)absorption (ABS) test was positive in the CSF sample. Serologic tests for human immunodeficiency virus (HIV) and other diseases were negative. Twenty four million units per day were given

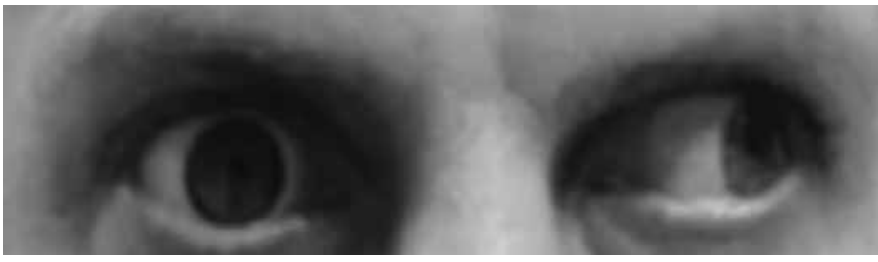

Figure 1. Impairment of right eye in inward looking

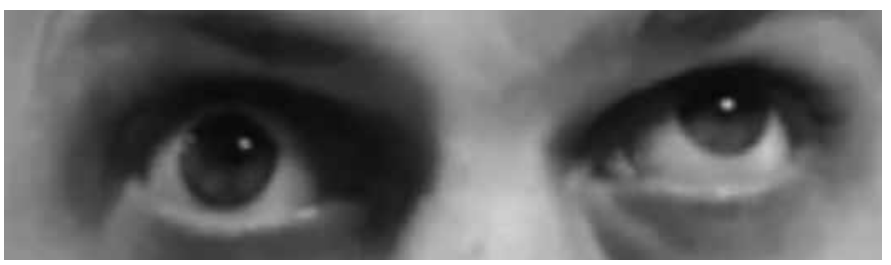

Figure 2. Impairment of right eye in upward looking

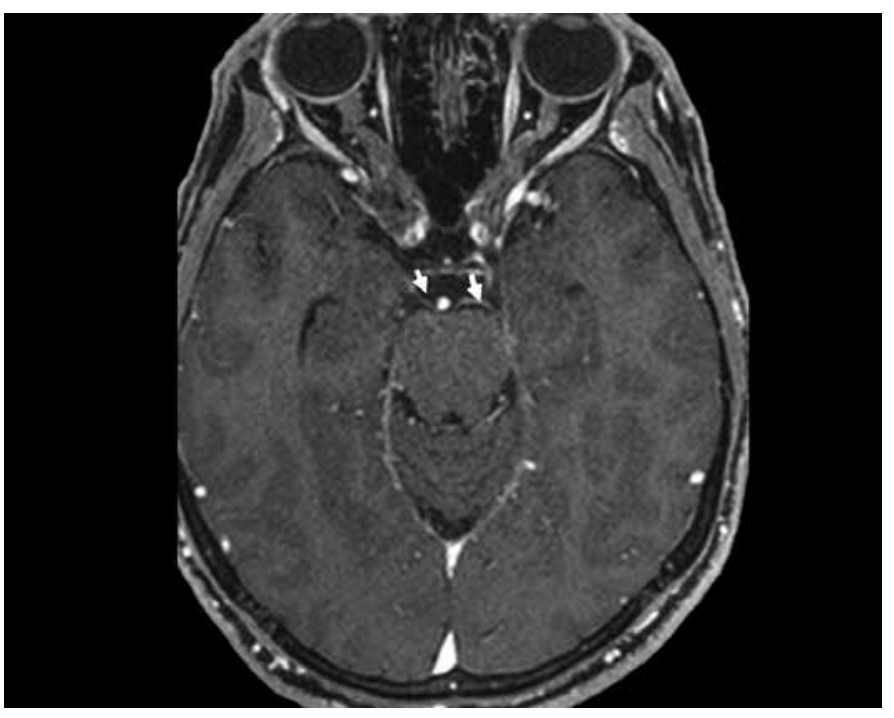

Figure 3. Contrast enhancements in bilateral 3. cranial nerves for three weeks. Ptosis improved on the first week of treatment. Repeated CSF investigation was normal. A rapid improvement in clinical state was achieved.

\section{Discussion}

Syphilis was called "the great imitator" in the past because it can manifest almost any symptom. It was considered in differential diagnosis of any ocular problems in past times when it was more common (2). In the antibiotic era, the number of patients with the classic form of neurosphilis has decreased while the frequency of subtle and atypical forms has increased $(3,4)$. These atypical presentations cause problems in the diagnosis of neurosyphilis.

Syphilis is a sexually-transmitted disease and unsafe sexual practices among homosexuals and number of patients with HIV increase its frequency. It presents in three stages. Primary stage presents with chancre and regional lymphadenopathy, which turns to the secondary stage within 2-4 weeks through the spread of microorganism via blood circulation, if no treatment is given. In this stage, involvement of CNS and aseptic meningitis can be seen. After symptoms of the secondary stage ameliorate, the tertiary stage begins following at least five years of a latent period.

CNS involvement can be seen weeks or years after the initial infection in any stage of the disease. CNS involvement is usually seen in the tertiary stage but also in the secondary stage. Acute syphilitc meningitis, meningovascular syphilis, and parenchymal neurosyphilis are major presentations of the disease; however, most patients are asymptomatic $(5,6)$.

Parenchymal neurosyphilis is associated with widespread parenchymal damage and demyelination of dorsal root ganglions, which presents as tabes dorsalis. Meningovascular syphilis presents with focal neurologic signs and global dysfunction of CNSinvolving seizures, hemiplegia, insomnia, personality changes, and dementia. Acute syphilitic meningitis presents with headache, confusion, and meningeal irritation signs. Meningeal irritation can effect cranial nerves at the brain and cause cranial neuropathies. Meningeal irritation can effect cranial nerves at the brain and cause

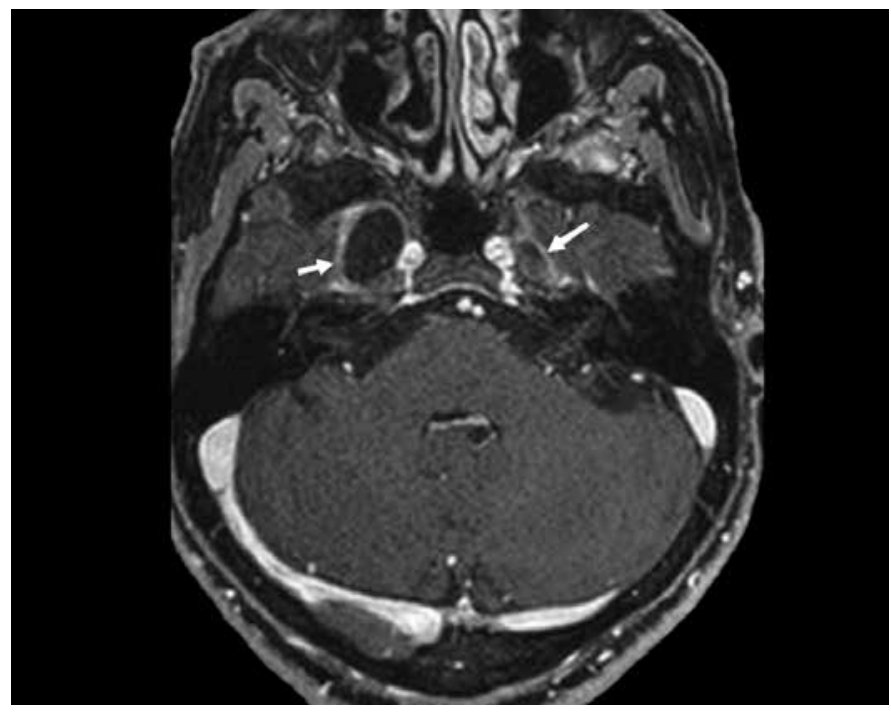

Figure 4. Contrast enhancements in bilateral 7. cranial nerves 
cranial neuropathies which the $7^{\text {th }}$ and $8^{\text {th }}$ cranial nerves are the commonly effected nerves. Involvement of the $2^{\text {nd }}, 3^{\text {rd }}$, and $6^{\text {th }}$ cranial nerves have also been reported (7).

Our patient was admitted to the emergency department with cranial neuropathies without meningeal irritation signs. Neurologic examination showed involvements of $3^{\text {rd }}, 5^{\text {th }}$, and $8^{\text {th }}$ cranial nerves and dorsal root ganglions.

In neurosyphilis, cranial nerve involvement is caused by basilar meningitis, which causes inflammation; in the meningovascular form, ischemia of nerves or compression of gummas may cause cranial nerve involvement (8). Multiple cranial nerve involvement suggested the syphilitic basilar meningitis form of the disease in our patient.

Cranial imagings may show various findings in patients with neurosyphilis (Table 1) (9). Cranial MRI showed contrast enhancement in the $3^{\text {rd }}, 5^{\text {th }}, 7^{\text {th }}$, and $8^{\text {th }}$ cranial nerves and no parenchymal involvement in our patient.

Neoplastic, granulomatous, infectious processes may cause cranial nerve involvement. Our patient had no history of malignancy, which excluded the diagnosis of leptomeningeal carcinomatosis and lymphoma. The diagnosis of granulomatous meningitis secondary to systemic sarcoidosis was excluded because there was no optic chiasm involvement, the CSF Angiotensinconverting enzyme level was normal, and thorax CT was normal. Serologic tests for herpes simplex, varicella, citomegalovirus, HIV, Lyme disease, and tuberculosis were negative.

Our patient had no history of sexually-transmitted disease and level of anti-HIV antibodies in serum was negative. However, in seroconversion time, patients may not have detectable levels of HIV antibodies in the blood, so we planned to repeat the test 3 months later. Syphilis is mostly sexually transmitted but there are other routes of transmission. In our patient's wife, VDRL and

\begin{tabular}{l} 
Table 1. Cranial magnetic resonance imaging findings in \\
neurosyphilis \\
Cerebral atrophy \\
Cortico-subcortical infarctions \\
Infarctions in brain stem and basal ganglia \\
Leptomeningeal contrast enhancement \\
Syphilitic gummas \\
Lepto-meningeal granuloma \\
Non-specific white matter changes \\
Arteritis (especially Heubner arteritis) \\
\hline
\end{tabular}

FTA-ABS tests were negative, which suggests the disease could have been acquired in childhood in our patient.

Positive serum VDRL-RPR and TPHA and CSF FTA-ABS tests and rapid improvement in clinical state and CSF findings to intravenous penicillin treatment suggested the diagnosis of neurosyphilis in our patient.

We want to highlight that neurosyphilis can present with any symptoms. In a conscious patient with multiple cranial nerve involvements without meningeal irritation signs, neurosyphilis must be kept in mind in the differential diagnosis.

\section{Ethics}

Informed Consent: Consent form was filled out by all participants. Peer-review: External and internal peer-reviewed.

\section{Autborship Contributions}

Concept: Eda Kılı̧̧ Çoban, Aysun Soysal, Design: Eda Kılı̧̧ Çoban, Mesude Özerden, Nilïfer Kale, Data Collection or Processing: Eda Kılıc Çoban, Mebmet Ali Aldan, Sedat Gez, Analysis or Interpretation: Eda Kılı̧ Çoban, Literature Search: Eda Kılıç Çoban, Mebmet Ali Aldan, Nazan Sakall, Writing: Eda Kılı̧ Çoban.

Conflict of Interest: No conflict of interest was declared by the authors. Financial Disclosure: The authors declared that this study has received no financial support.

\section{References}

1. Smith GT, Goldmeier D, Migdal C. Neurosyphilis with optic neuritis: an update. Postgrad Med J 2006;82:36-39.

2. Tamesis RR, Foster CS. Ocular syphilis. Ophthalmology 1990;97:12811287.

3. Ropper AH, Brown RH. Adams and Victor's Principles of Neurology. Sinir sistemi enfeksiyonları. 8. basım. İstanbul: Güneş Kitabevi, 2006:531-592.

4. Rowland LP, Stefanis L. Merritt's neurology. Spirochete infections 11th. New York: Lippincott Williams and Wilkins, 2005:235-242.

5. Harris DE, Enterline DS, Tien RD. Neurosyphilis in patients with AIDS. Neuroimaging Clin N Am 1997;7:215-221.

6. Holland BA, Perrett LV, Mills CM. Meningovascular syphilis: CT and MR findings. Radiology 1986;158:439-442.

7. Falcone S, Quencer RM, Post MJ. Magnetic resonance imaging of unusual intracranial infections. Top Magn Reson Imaging 1994;6:41-52.

8. Hadrane L, Waterkeyn F, Ghijselings L, Dhaene N, Gille M. Neurosyphilis revealed by a multiple cranial neuropathy: magnetic resonance imaging findings. Rev Neurol (Paris) 2008;164:253-257.

9. Brightbill TC, Ihmeidan IH, Post MJ, Berger JR, Katz DA. Neurosyphilis in HIV-positive and HIV-negative patients: neuroimaging findings. AJNR Am J Neuroradiol 1995;16:703-711. 